\title{
L'Attention
}

\section{The double meaninf of différance : remarks on its first appearance}

Daniele De Santis

\section{(2) OpenEdition}

1 Journals

\section{Electronic version}

URL: http://journals.openedition.org/alter/1743

DOl: $10.4000 /$ alter. 1743

ISSN: 2558-7927

Publisher:

Association ALTER, Archives Husserl (CNRS-UMR 8547)

\section{Printed version}

Date of publication: 1 October 2010

Number of pages: 297-304

ISBN: 2-9522374-6-8

ISSN: $1249-8947$

\section{Electronic reference}

Daniele De Santis, «The double meaninf of différance : remarks on its first appearance », Alter [Online] 18 | 2010, Online since 01 June 2020, connection on 27 June 2020. URL : http://

journals.openedition.org/alter/1743; DOI : https://doi.org/10.4000/alter.1743 


\section{THE DOUBLE MEANING OF DIFFÉRANCE : REMARKS ON ITS FIRST APPEARANCE}

Daniele De Santis

It is in 1965 that, as well known, Derrida publishes in Tel Quel one of his most important writings on Antonin Artaud: La parole soufflée. In what follow, however, the deep meaning of such an essay is not immediately related to the specifically Artaudian questions it arises, but to the fact that Derrida's most famous neologism - différance - makes between its pages (for three times) the first appearance. It is in any case important to keep in mind the distinction between its two different editions: Derrida himself, by republishing the essay two years later in L'écriture et la différence (1967), has modified it including furthermore four new additions of "différance". Here the passages in question:

Inspiration is the drama, with several characters, of theft, the structure of the classical theater in which the invisibility of the prompter [souffleur] ensures the indispensable différance and intermittence between a text already written by another hand and an interpreter already dispossessed of that which he receives ${ }^{1}$.

And this différance, these delays, this relay of representation extend and liberate the play of the signifier, thus multiplying the places and moments of elusion ${ }^{2}$.

Their origin and active movement-differing, différance-are enclosed ${ }^{3}$.

Furtive différance could not have insinuated itself with the aid of writ-ing but, rather, slipped in between two forms of writing, thereby placing my life outside the work and making its origin - my flesh - into the epigraph and breathless sarcophagus of my discourse 4 .

1. Jacques Derrida, "La parole soufflée", in L'écriture et la différence, Paris, Seuil, 1967, p. 262. We have taken into account also the English translation by Alan Bass as Writing and Difference, Chicago, University of Chicago, 1992.

2. J. Derrida, L'écriture et la différence, op. cit., p. 286.

3. Ibid., p. 288.

4. Ibid., p. 289. 


\section{L'attention}

While in the first, second and fourth quotation just the single différance is added in 1967, the third quotation is totally absent from the first version.

Nevertheless, before beginning our analysis and reconstruction of the philosophical setting and discussion wherein Derrida writes for the first time the word différance, we should recall a very important Eberhard Gruber's essay with his hypothesis on the first appearance of the neologism ${ }^{5}$. Discussing about the three different editions of the text "La différance", Gruber remarks in a footnote: "Derrida mentions for the first time the word différance probably in 1959 during his lecture in Cerisy-la-Salle "'Genèse et structure' et la phénoménologie", of which only the publication in L'écriture et la différence (Paris, Seuil, 1967, p. 239) enables to read the homophony". Here the passage from L'écriture et la différence quoted by Gruber :

\section{This irreducible difference is due to an interminable différance of the theoretical foundation ${ }^{6}$.}

Certainly, we don't have the first version of "'Genèse et structure' et la phénoménologie" (1959), but just its first publication of 1965 as essay in Entretiens sur les notions de genèse et de structure 7 , at the beginning of the which the editors have added a footnote to remark: "Mr. Derrida, which has reassessed and completed his text, has added a certain number of explicative notes and references" 8 . If at this point we recall the same passage quoted by Gruber, from the same text, but from this older edition, we could read :

This irreducible difference is due to an interminable difference of the theoretical foundation ${ }^{9}$.

Gruber never takes into account the text of 1965, but only its republication (with the addition of a différance) in L'écriture et la différence, presupposing the first appearance in 1959: in this way we find ourselves in a paradoxical situation in which we have différance (according to Gruber) in "'Genèse et structure' et la phénoménologie" (1959); not in the same text six years later (1965) but only in "La parole soufflée" and then, once more, in "Genèse et structure" in L'écriture et la différence (1967). On the first appearance of différance in the text on Artaud one can find a further evidence in the fact that Élisabeth Roudinesco, talking with Derrida about a politics of difference, refers the reader to "La parole soufflée" for such a first Derridean use of

5. Eberhard Gruber, "Différ()nce", in Marie-Louise Mallet, Ginette Michaud (éds.), Derrida, Paris, L'Herne, 2004, p. 191-198.

6. Jacques Derrida, "'Genèse et structure' et la phénoménologie”, in L'écriture et la différence, p. 239.

7. Jacqued Derrida, “'Genèse et structure' et la phénoménologie”, in Maurice de Gandillac, Lucien Goldmann, Jean Piaget (eds.), Entretiens sur les notions de genèse et de structure, Paris, Mouton, 1965, p. 243-260.

8. Ibid., p. 243 in footnote.

9. Ibid., p. 251. 
différance ${ }^{10}$ : in any way, by recalling only the text of 1967 (as Roudinesco does), and never the original edition of 1965, we run the risk to take into account also the four other additions of différance.

$$
* * *
$$

The speculative setting of Derridean analysis oscillates between two kinds of metaphysics : on the one hand there is the dualistic metaphysics against which Artaud writes: metaphysics of differences and oppositions between soul and body, speech and existence; it is a metaphysics of expropriation and dissociation: "the theft of speech is not a theft among others; it is confused with the very possibility of theft"11 - ; on the other hand a "metaphysics of subjectivity" which is "powerfully at work in Artaud's thought"12; "metaphysics of subjectivity" or "metaphysics of life"13, "metaphysics of flesh which determines Being as life"14 and as "property" : Proper is the name of the subject close to himself"15. It is in such a philosophical context in such a dualism or conflict between dualism (metaphysics of difference and opposition) and monism ("Artaud teaches us this unity prior to dissociation") - that différence makes its first and absolute appearance :

There we already find prescribed a descent towards the depth at which the distinction of theatrical organs (author-text/director-actor-public), in the manifestation of forces, no longer would be possible. Now this system of organic divisions, this différance, has never been possible, except when distributed around an object, book, or libretto ${ }^{16}$.

Here différance means "system of organic divisions", namely not a single difference or a set of specific distinctions, but the systematic whole of metaphysical differences and oppositions as such against which Artaud argues to reestablish the "unity prior to dissociation".

One page later, discussing once more about speech and its theft, the second différance :

To let one's speech be spirited away is, like writing itself, the urphenomenon of the reserve: the abandoning of the self to the furtive, to discretion and separation, is, at the same time, accumulation, capitalization, the security of the delegated or deferred decision. To leave one's speech to the furtive is to tranquilize oneself into différance, that is to say, into economy ${ }^{17}$

10. Jacques Derrida, Élisabeth Roudinesco, De quoi demain... Dialogue, Paris, Galilée, 2001, chapter two.

11. J. Derrida, L'écriture et la différence, op. cit., p. 262.

12. Ibid., p. 265.

13. Ibid., p. 266.

14. Ibid., p. 268.

15. Ibid., p. 272.

16. Ibid., p. 284

17. Ibid., p. 285. 


\section{L'attention}

It is important to remark the words "reserve", "accumulation", "capitalization" and "economy", because it is in another very similar philosophical and economic context - in De la grammatologie's first edition (December 1965/January 1966) - that we can find a différance. Here the passage directly quoted from Critique :

\footnotetext{
If we could quote the expression ventured by Leroi-Gourhan, one could speak of a "liberation of memory", of an exteriorization of the trace which, beginning from the elementary programs of so-called "instinctive" behavior up to the constitution of electronic card-indexes, enlarges the difference (we would say différance) and the possibility of putting in reserve: it at once and in the same movement constitutes and effaces so-called conscious subjectivity, its logos, and its theological attributes 18
}

The last différance (we come back to "La parole soufflée") appears at the end of the writing, where Derrida sums his analysis on the two metaphysics - "as the metaphysics of inalienable life and historic indifference... as the metaphysics which lives within difference, within metaphor and the work, and thus within alienation"19 ${ }^{\prime}$, their inner solidarity and complicity. Here the quotation :

\footnotetext{
Now difference or differrance, with all the modifications laid bare by Artaud - can only be conceived as such beyond metaphysics, towards the Difference or Duplicity - of which Heidegger speaks. It could be thought that this latter Difference, which simultaneously opens and conceals truth, and in fact distinguishes nothing - the invisible accomplice of all speech - is furtive power itself, if this were not to confuse the metaphysical and metaphorical category of the furtive with that which makes it possible 20 .
}

This passage is not easy to interpret because of the recalling of Heideggerian Difference, and of the relation that binds this latter to différance itself through the preposition "towards": "towards the Difference or Duplicity". On the one hand in fact we have difference and différance, on the other hand Difference and Duplicity, so that thinking the former "towards the Difference or Duplicity" could mean at the same time taking différance as Difference or simply considering différance - "system of organic divisions" starting from Heideggerian Difference and Duplicity. But the second part of the quotation asserts precisely that "It could be thought that... Difference... is furtive power itself", but "this were to confuse the metaphysical and metaphorical category... with what which makes it possible". According to

18. Jacques Derrida, "De la grammatologie II", Critique, January 1966, p. 23-53: p. 46. In this first edition différance appears a second time at the end of the text: "This common root, that we have strategically nicknamed trace, reserve, or différance, could be called writing and system of written signs only within the historical closure of both science and philosophy" (ibid., p. 53).

19. J. Derrida, L'écriture et la différence, op. cit., p. 290.

20. Ibid., p. 291-292. 
this last sentence the difference between différance and Difference is the difference between the "system of organic divisions" as "furtive power" or "theft" and its condition of possibility; between "metaphysics" or "metaphor" - "It is the metaphor that Artaud wants to destroy"21 as phenomenon of difference 22 - and its non-metaphorical and nonmetaphysical origin. In other words : différance means, the first time Derrida has made use of it, the metaphysics itself as expropriation and dissociation : i.e., not a deferring or delaying movement but the systematic whole of metaphysical differences thought, as such, in the light (literally) of Heidegger's ontological Difference ${ }^{23}$. The situation, here, seems to be exactly the opposite of the lecture "La différance" (1968), where "différance, in a certain and very strange way, (is) "older" than the ontological difference", to such an extent to become "the historical and epochal unfolding of Being or of ontological difference" :

$$
\begin{aligned}
& \text { are not the thought of the meaning or truth of Being, the determination of } \\
& \text { différance as the ontico-ontological difference, difference thought within the horizon } \\
& \text { of the question of Being, still intrametaphysical effects of différance }{ }^{24} \text { ? }
\end{aligned}
$$

Here the essential features of Derrida's theoretical position developed throughout "La différance" : as every single (intra-metaphysical) difference is thought within the horizon of Being, namely within the horizon of onticoontological difference, as this latter, in its turn, is thought within the horizon of différance. Derrida writes that "this is why the Heracliteian play of the hen diapheron heauto, of the one différant from itself, the one in conflict with itself, already is lost like a trace in the determination of the diapherein as ontological difference" 25 . We can present schematically such a situation in this way:

\section{Ibid., p. 275}

22. Ibid., p. 267: "If difference, within its phenomenon, is the sign of theft or of the purloined breath, it is primarily, if not in itself, the total dispossession".

23. Following this reconstruction of the appearance of différance we cannot agree, at least philologically, with Lawlor's hypothesis, according to which "Derrida's concept of différance derives from the Husserlian concept of intentionality", Leonard Lawlor, Derrida and Husserl. The Basic Problem of Phenomenology, Bloomington \& Indianapolis, Indiana University Press, 2002, p. 3. On the contrary, différance is originally conceived to think and translate grammatically the concept of (Heideggerian) metaphysics. See furthermore Dominique Janicaud, "Jacques Derrida", in Heidegger en France. II, Paris, Hachette, 2001, p. 89-126: p. 96. In this interview Derrida confesses us he studied Heidegger between the years 1960 and 1965, with a lecture an the university, in the academic year 1965-1966, on "L'histoire chez Heidegger" that at the last moment he decided (with the title La question de l'histoire) to not publish as book. In effect, we have flipped through the pages of Critique between the years 1965 and 1970: a Derrida's text is always announced, but with the title Les questions de Heidegger, until 1970. In any case, this interview sustains our reconstruction of the first Heideggerian context of différance.

24. Jacques Derrida, "La différance", in Marges de la philosophie, Paris, Minuit, 1968, p. 1-29: p. 23.

25. For other references to Heraclites, see J. Derrida, Marges - de la philosophie, op. cit., p. 8;

"L'oreille de Heidegger. Philopolémologie", in Politiques de l'amitié suivi de L'oreille de Heidegger, 


\section{L'attention}

différance or diapherein $\rightarrow$ ontico-ontological difference $\rightarrow$ intrametaphysical differences

On the contrary, according to "La parole soufflée" (1965), meaning différance nothing else but the metaphysics as totality of differences and expropriations to think starting from Heideggerian Difference - and this latter, as Derrida also writes in 1964, not simply has "a sense", because "it is sense" 26 - the schematic presentation would be very different :

Heidegger's Difference or Duplicity $\rightarrow$ différance or "system of organic divisions" $\rightarrow$ differences

To better understand the meaning of such a first appearance of différance we would briefly take into account some of the additions from L'écriture et la différence, starting from the long new passage added at the end of the writing after Heidegger's Difference and Duplicity ${ }^{27}$. Here Derrida adds that Artaud "keeps himself at the limit", the limit between metaphysics of alienation or difference and metaphysics of property : on one side "Artaud's "metaphysics", at its most critical moments, fulfills the most profound and permanent ambition of Western metaphysics", but on the other side "Artaud affirms the cruel... law of difference; a law that this time is raised to the level of consciousness and is no longer experienced within metaphysical naiveté" 28 . In this way Derrida alters, if not the theoretical setting itself, at least his interpretation of such a setting: while in 1965 in fact he considered as the deepest meaning of Artaud's metaphysics the concepts of "property" and of subjectivity close to himself and without differences, here Derrida suggests that the true meaning of Artaud's metaphysics consists in raising "to the level of consciousness" the cruel law of difference itself. In this way, Artaud's reconstruction of "unity prior to dissociation" unfolds at the same time two contradictory meanings: according to first it accomplishes the "permanent ambition of Western metaphysics" ("metaphysics of inalienable

Paris, Galilée, 1994, p. 341-419: p. 414; "Nous autres Grecs", in AA. Vv., Nos Grecs et leurs modernes, Paris, Seuil, 1992, p. 273; Jacques Derrida, Maurizio Ferrarsi, Il gusto del segreto, RomaBari, Laterza, 1997. For the origin of the Heracliteian hen diapheron heauto, quoted by Derrida himself several times, see Friedrich Hölderlin, "Hyperion", in Werke und Briefe, Bd. I, Frankfurt a. M., Deutscher Klassiker Verlag, 1992, p. 367: “Das große Wort, daß - en diapheron eauto, das eine in sich selber Unterschiedne - des Heraklit, das konnte nur ein Grieche finden, das es ist das Wesen der Schönheit, und ehe das gefunden war, gabs keine Philosophie".

26. J. Derrida, "Violence et métaphysique", in L'écriture et la différence, op. cit., p. 117-228: p. 200: "Mais si l"ontologie' n'est pas un truisme, ou du moins un truisme parmi d'autres, si l'étrange différence entre l'être et l'étant a un sens, est le sens, peut-on parler de 'priorité' de l'être par rapport à l'étant [n.s.]?".

27. Ibid., all the text from "Artaud se tient sur la limite" (p. 291) to "risque toujours de retourner à la métaphysique" (p. 292) is added in 1967.

28. Ibid., p. 291. 
life and historic indifference"), but according to second we should conceive the attempt to go beyond the differences not as an attempt to realize an undifferentiating life but, on the contrary, to become conscious of differences qua differences or of their delaying and differing movement.

To enforce this reconstruction of différance's double meaning in 1967 we want to quote another addition too. In the same short passage where différance has made the first appearance - and where Artaud opposes to the "system of organic divisions" as "theft of speech" the necessity of an "illegibility" : "In theatrical illegibility, in the night that precedes the book, the sign has not yet been separated from force" - Derrida adds in 1967: It is not quite yet a sign, in the sense in which we understand sign, but is no longer
a thing, which we conceive only as opposed to the sign ${ }^{29}$.

Asserting "it is not quite yet a sign" is asserting that such an "illegibility" - totally indifferent to differences in 1965 - has to become a sign. It is asserting, being the "sign" just phenomenon of difference, that it has to become (it is not quite yet a difference) difference: its un-postponable differing and delaying. While "illegibility" means in 1965 the mythic place of "inalienable life and historic indifference", becomes in 1967 the place itself which is still prior to differences and expropriations, but not as their opposite, rather as what, by changing the viewpoint, takes back "to the level of consciousness" the differences themselves in their differentiation.

Here the double sense of différance. And this particular duplicity is due to the fact that Derrida, republishing "La parole soufflée" two years later in L'écriture et la différence, superimposes to the first meaning of 1965 - différance as metaphysical system of divisions and differences thought in the light of Heidegger's Difference - a second and more articulated meaning of différance as a differing older than the ontico-ontological difference. In this way the situation we should face at the end of this our analytical reconstruction is the one related to the semantic opposition, or even antinomy, between these two kinds of différance: if on the one hand in fact we have a metaphysics of oppositions, crystallizations and petrifactions and on the other hand the active, dynamic and kinetic delaying, the question which rises is - "How is it possible, or in what way the differing movement, nothing else but an Heracliteian river, could paralyze itself to such an extent to become a system of oppositions and organic divisions?". Because there is certainly, between these two "différance", identity of names, but also a so radical constitutional or "ontological" (we use inverted commas) heterogeneity to forbid something as a conceptual communication or possible transit between them. 
SYNOPTIC TABLE ON LA PAROLE SOUFFLÉE ${ }^{30}$

\begin{tabular}{|c|c|}
\hline 1965 & 1967 \\
\hline $\begin{array}{l}\text { First appearances } \\
\text { "There we already find prescribed a } \\
\text { descent toward the depth at which the } \\
\text { distinction of theatrical organs (author- } \\
\text { text/director-actor-public), in the } \\
\text { manifestation of forces, no longer would } \\
\text { be possible. Now this system of organic } \\
\text { divisions, this différance, has never been } \\
\text { possible, except when distributed } \\
\text { around an object, book, or libretto" } \\
\text { (p. 284). } \\
\text { "To let one's speech be spirited away is, } \\
\text { like writing itself, the urphenomenon of } \\
\text { the reserve : the abandoning of the self to } \\
\text { the furtive, to discretion and separation, } \\
\text { is, at the same time, accumulation, } \\
\text { capitalization, the security of the } \\
\text { delegated or deferred decision. To leave } \\
\text { one's speech to the furtive is to } \\
\text { tranquilize oneself into différance, that is } \\
\text { to say, into economy" (p. 285). } \\
\text { "Now difference or différance, with all the } \\
\text { modifications laid bare by Artaud - can } \\
\text { only be conceived as such beyond } \\
\text { metaphysics, towards the Difference or } \\
\text { Duplicity - of which Heidegger speaks. } \\
\text { It could be thought that this latter } \\
\text { Difference, which simultaneously opens } \\
\text { and conceals truth, and in fact } \\
\text { distinguishes nothing - the invisible } \\
\text { accomplice of all speech - is furtive } \\
\text { power itself, if this were not to confuse } \\
\text { the metaphysical and metaphorical } \\
\text { category of the furtive with that which } \\
\text { makes it possible" (p. 291-292). }\end{array}$ & $\begin{array}{l}\text { Additions } \\
\text { "Inspiration is the drama, with several } \\
\text { characters, of theft, the structure of the } \\
\text { classical theater in which the invisibility } \\
\text { of the prompter ensures the } \\
\text { indispensable différance and } \\
\text { intermittence between a text already } \\
\text { written by another hand and an } \\
\text { interpreter already dispossessed of that } \\
\text { which he receives" (p. 262). } \\
\text { "And the différance, these delays, this } \\
\text { relay of representation extend and } \\
\text { liberate the play of the signifier, thus } \\
\text { multiplying the places and moments of } \\
\text { elusion" (p. 286). } \\
\text { "Their origin and active movement - } \\
\text { differing, différance - are enclosed" } \\
\text { (p. 288). } \\
\text { "Furtive différance could not have } \\
\text { insinuated itself with the aid of writ-ing } \\
\text { but, rather, slipped in between two } \\
\text { forms of writing, thereby placing my life } \\
\text { outside the work and making its origin - } \\
\text { my flesh - into the epigraph and } \\
\text { breathless sarcophagus of my discourse" } \\
\text { (p. 289). }\end{array}$ \\
\hline
\end{tabular}

Daniele De Santis Scuola Superiore di Studi in Filosofia University of Rome II "Tor Vergata"

30. The pages are quoted from Jacques Derrida, L'écriture et la différence, Paris, Seuil 1967. 